\title{
NBAS wt Allele
}

National Cancer Institute

\section{Source}

National Cancer Institute. NBAS wt Allele. NCI Thesaurus. Code C54365.

Human NAG wild-type allele is located within 2p24 and is approximately 394 kb in length.

This allele, which encodes neuroblastoma-amplified protein, plays a putative role in the development of neuroblastoma. 